\title{
IMPROVING STUDENTS ACTIVITIVY AND STUDENTS ACHIEVEMENT IN LEARNING PKN BY USING ROLE PLAY STRATEGY AT THE TENTH GRADE STUDENTS OF SMA EKA SAKTI PADANG
}

\author{
SYAFRIAL
}

Volume 2 Nomor 1

JIPS ISSN: 2579-5449

\begin{abstract}
This research is based on the activity of formulation of PPKN problem through role playing strategy at the tenth grade students of SMA Eka Sakti Padang, and implementation and assessment of KDPN learning that can improve learning result with role playing strategy at the tenth grade students of SMA Eka Sakti Padang,. Based on the data processing and discussion conducted, the results obtained at cycle time 6.96 and increased in cycle II through 8.57. The

research method used is classroom action research (classroom action research). Based on the results of the study, it can be concluded that the successful implementation of research that has been done in SMA Eka sakti Padang. Based on the results of the study, it can be concluded that there is an increase in student learning outcomes of grade tenth in SMA Eka sakti Padang significant on learning PPKN by using role playing strategy.
\end{abstract}

Keywords: Role Strategies, Activities and Learning Outcomes

\section{PENINGKATAN AKTIVITAS DAN HASIL PEMBELAJARAN PPKN DENGAN STRATEGI ROLE PLAYING DI KELAS X SMA EKA SAKTI PADANG}

\begin{abstract}
ABSTRAK
Penelitian ini dilatar belakangi oleh kurangnya aktivitas dalam proses pembelajaran dan bertujuan untuk meningkatkan proses pembelajaran PPKN melalui strategi role playing di kelas X SMA Eka sakti Padang, serta pelaksanaan dan penilaian pembelajaran PPKN yang dapat meningkatkan hasil belajar dengan strategi role playing di kelas X SMA Eka sakti Padang. Berdasarkan pengolahan data dan pembahasan yang dilakukan, diperoleh hasil pada siklus I yakni 6,96 dan mengalami

peningkatan pada siklus II yakni 8,57. Metode penelitian yang digunakan adalah penelitian tindakan kelas (class room action research). Berdasarkan hasil penelitian, dapat disimpulkan bahwa adanya keberhasilan pelaksanaan penelitian yang telah dilakukan di SMA Eka sakti Padang. Berdasarkan hasil penelitian, dapat disimpulkan bahwa adanya peningkatan hasil belajar siswa kelas X SMA Eka sakti Padang yang signifikan pada pembelajaran PPKN dengan menggunakan strategi role playing
\end{abstract}




\section{PENDAHULUAN}

Pembelajaran merupakan proses yang mengandung serangkaian perbuatan guru dan siswa atas hubungan timbal balik yang berlangsung dalam situasi edukatif dalam mencapai tujuan tertentu. Interaksi atau hubungan timbal balik antara guru dan siswa merupakan syarat utama bagi berlangsungnya proses pembelajaran. Dalam rangka meningkatkan mutu pendidikan di Sekolah Menengah Atas (SMA) telah banyak usaha yang dilakuan oleh pemerintahan. Usaha-usaha tersebut antara lain adalah memberikan pelatihan-pelatihan kepada Sekolah Menengah Atas (SMA) dengan berbagai jenis kegiatan, pengadaan buku-buku sumber, penyempurnaan dan pemanfaatan kurikulum, melakukan penyempurnaan sarana dan prasarana sekolah, mengadakan kegiatan-kegiatan Kelompok Kerja Guru (KKG), dan lain-lainnya. Namun usahausaha tersebut belum terlaksana sepenuhnya di sekolah menengah pertama karena masih banyaknya guru-guru yang masih mengajar secara konvensional dalam pembelajaran, masih sedikit guru yang melakukan perubahan terhadap sebuah pembelajaran, tidak menggunakan media serta dalam menyajikan materi masih menggunakan metode ceramah.

Menurut Depdikbud (1997:1) usaha peningkatan hasil belajar belum berhasil dengan baik dalam proses pembelajaran hal ini disebabkan oleh; 1) Masih banyak guru yang mengajar secara klasikal, 2) Kebanyakan kegiatan siswa adalah mendengarkan penjelasan guru, 3) Mengutamakan menghafal pengetahuan dan rumus-rumus daripada mengembangkan keterampilan dan kemampuan berfikir yang diperlukan dalam kehidupan sehari-hari dan masa yang akan datang, 4) Sedikitnya kesepadanan bahan pengajaran dengan metode dan kemampuan setiap siswa, 5) Hasil belajar rendah,kemampuan memecahkan masalah rendah berdasarkan kemampuan dan keterampilan yang diperoleh, dan 6) Lingkungan kelas yang bising menyulitkan untuk komunikasi dan belajar yang memerlukan pemikiran".

Belajar merupakan inti dari proses pembelajaran. Dengan mengetahui tentang belajar kita akan dapat melaksanakan proses pembelajaran secara efektif. Darsono (2004:24) mengemukakan bahwa beajar merupakan suatu kegiatan yang mengakibatkan terjadinya perubahan tingkah laku. Senada dengan pengertian di atas, Slameto (1995:2) mengartikan belajar adalah "...suatu proses usaha yang dilakukan seseorang untuk memperoleh suatu perubahan tingkah laku yang baru dilakukan seseorang untuk memperoleh suatu perubahan tingkah laku yang baru secara keseluruha, sebagai hasil pengalamannnya sendiri dalam interaksi dengan lingkunganya.

Sedangkan, Hasil belajar menurut Bloom dalam Harun dan Mensur, (2007:13) "mencakup peringkat dan tipe prestasi belajar, kecepatan belajar,dan hasil efektif". Sedangkan menurut Sudjana (2004:22) "hasil belajar adalah kemampuan-kemampuan yang dimiliki siswa setelah ia menerima pengalaman belajar'.

Pembelajaran adalah satu kata yang mempunyai kata dasar "belajar" yang diberi awalan pe- dan akhiran -an. Pembelajaran menurut Cagne dan Biggs (dalam Djafar 2001:10) adalah "Rangkaian peristiwa/kejadian yang mempengaruhi siswa sedemikian rupa sehingga proses belajarnya dapat dapat berlangsung dengan mudah". Natawijaya (1992:59) menyatakan bahwa "Pembelajaran adalah upaya pembimbingan terhadap siswa agar siswa itu secara sadar dan terarah berkeinginan untuk belajar dan memperoleh hasil belajar sebaik-baiknya sesuai dengan keadaan dan kemampuan siswa yang bersangkutan". Sedangkan Rohadi (2003:6) menyatakan "Istilah pembelajaran lebih menggambarkan usaha guru untuk membuat belajar para siswanya. Kegiatan pembelajaran tidak akan berarti jika tidak menghasilkan kegiatan belajar siswa“.

PPKN ditetapkan atas ketentuan yang tersirat dalam Undang-Undang No.20 Tahun 2003 pasal 39 ayat 1. Penjelasan tersebut menyatakan "PPKN mengarahkan pada moral yang diharapkan dapat mewujudkan dalam kehidupan sehari-hari”.

Menurut Winataputra (2006:428) tujuan PPKN adalah: "untuk mengembangkan potensi individu warga negara Indonesia sehingga memiliki wawasan, posisi, dan keterampilan PPKN yang memadai dan memungkinkan untuk berpartisipasi secara cerdas dan bertanggung jawab dalam berbagai dimensi kehidupan bermasyarakat, bebangsa, dan bernegara di Indonesia".

Menurut Djamarah (2007:1) "Metode adalah ilmu yang mempelajari cara-cara untuk melakukan aktifitas yang tersistem dari sebuah 
lingkungan yang terdiri dari pendidik dan siswa untuk saling berinteraksi dalam melakukan suatu kegiatan sehingga proses pembelajaran berjalan dengan baik".

Oemar (2005:199) menyatakan "Bermain peran atau teknik sosiodrama adalah suatu jenis teknik simulasi yang umumnya digunakan untuk pendidikan sosial dan hubungan antar insani". Sedangkan menurut Nuryani (2005:110) "Metode bermain peran adalah pembelajaran dengan seolah-olah berada dalam suatu situasi untuk memperoleh suatu pemahaman tentang suatu konsep".

Nuryani (2005:110) menyatakan bahwa "Keunggulan dari metode bermain peran adalah siswa mendapat kesempatan terlibat secara aktif sehingga akan lebih memahami konsep dan akan lebih lama mengingat. Sedangkan kelemahan metode ini adalah dalam hal alokasi waktu".

Pembelajaran PPKN dengan menggunakan metode bermain peran akan mencapai hasil sesuai dengan tujuan yang telah ditetapkan apabila seorang guru memahami langkah-langkah pembelajaran metode bermain peran. Menurut Oemar (2008:215) langkahlangkah pembelajaran dengan metode bermain peran Yaitu: 1) Persiapan dan instruksi 2) Tindakan dramatik dan diskusi 3) Evaluasi bermain peran.

Menurut Haris (2007:3) penilaian adalah proses untuk mendapatkan informasi tentang prestasi atau kinerja siswa. Hasil penilaian digunakan untuk melakukan evaluasi terhadap ketuntasan siswa dan evektifitas proses pembelajaran. Sedangkan menurut Nana (1996:65) menyatakan bahwa penilaian adalah alat bantu untuk mengukur tercapai atau tidaknya tujuan pembelajaran. Penilaian pembelajaran PPKN bertujuan untuk memantau proses dan kemajuan belajar siswa serta untuk meningkatkan efektifitas kegiatan pembelajaran.

Berdasarkan kenyataan dan permasalahan yang telah ditemukan di atas, guru akan menemukan permasalahan yang sama pada pembelajaran PPKN. Untuk itu dalam proses pembelajaran PPKN di SMA Eka sakti Padang diperlukan suatu metode yang dapat meningkatkan hasil belajar siswa. Kemampuan menguasai metode pembelajaran merupakan syarat utama yang harus di miliki guru, karena kemampuan menguasai dan menggunakan metode yang tepat berpengaruh terhadap keberhasilan peserta didik baik keberhasilan dari segi aspek kognitif, afektif, dan psikomotor.

Berdasarkan hasil observasi dan wawancara dengan guru serta peninjauan langsung dalam kelas saat pembelajaran PPKN di SMA Eka sakti Padang, terbukti bahwa pelaksanaan pembelajaran yang di lakukan guru dominan dengan metode berceramah, guru bellum melibatkan siswa secara aktif falam pemeblajaran, siswa masih dominan menghafal pengetahuan dan rumus-rumus daripada mengembangkan keterampilan dan pengetahuan berfikir, serta bellum terbiasanya siswa terlibat dalam perannya sebagai pelaku yang terlibat langsung dalam kehidupan sekolah dan masyarakat sehingga hasil pembelajaran kurang maksimal. Berdasarkan masalah di atas penulis tertarik untuk melakukan penelitian tindakan kelas dengan judul "Peningkatan Aktivitas Dan Hasil Pembelajaran PPKN dengan Strategi Role Playing Di Kelas X SMA Eka sakti Padang”.

Adapun tujuan penelitian ini adalah sebagai berikut: (1) mendepenelitiankan bentuk Rencana Pembelajaran PPKN yang dapat meningkatkan hasil belajar dengan menggunakan metode bermain peran di kelas X SMA Eka sakti Padang, (2) mendepenelitiankan pelaksanaan pembelajaran PPKN yang dapat meningkatkan hasil belajar dengan menggunakan metode bermain peran di kelas X SMA Eka sakti Padang, (3) mendepenelitiankan penilaian pembelajaran PPKN yang dapat meningkatkan hasil belajar dengan metode bermain peran di kelas X SMA Eka sakti Padang.

\section{METODE PENELITIAN}

kelas dengan menggunakan pendekatan kualitatif. Jenis penelitian yang dilakukan merupakan penelitian tindakan kelas (action research) dibidang pendidikan dan pengajaran PPKN. Dalam penelitian tindakan kelas diadakan perlakuan tertentu yang didasarkan pada masalah-masalah aktual yang ditemukan di lapangan.

Penelitian ini dilakukan dengan menggunakan model siklus yang dikembangkan oleh Kemmis dan Mc Taggart dalam Ritawati (2008:69), proses penelitian merupakan proses daur ulang atau siklus yang dimulai dari aspek: 
mengembangkan perencanaan, melakukan tindakan sesuai rencana, melakukan observasi terhadap tindakan dan melakukan refleksi terhadap perencanaan.

Data penelitian ini dikumpulkan dengan menggunakan, lembar observasi, wawancara dan hasil tes. Untuk masing-masingnya diuraikan sebagai berikut: Pada dasarnya berupa paparan tentang latar pengamatan terhadap tindakan praktis sewaktu pembelajaran PPKN di SMA Eka sakti Padang di Kelas $\mathrm{X}$ dengan menggunakan metode bermain peran. Unsurunsur yang diamati dalam pelaksanaan mengacu pada apa yang tertera pada butir-butir lembar observasi. Di samping itu, juga memuat rancangan refleksi berdasarkan pengamatan yang dilakukan peneliti dengan cara observasi

Observasi dilakukan untuk mengamati latar kelas tempat berlangsungnya pembelajaran PPKN dengan menggunakan metode bermain peran. Dengan berpedoman pada lembar-lembar observasi penulis mengamati apa yang terjadi pada proses pembelajaran. Unsur-unsur yang menjadi butir-butir sasaran pengamatan bila terjadi dalam proses pembelajaran ditandai dengan memberikan ceklis pada kolom "tidak" akan dituliskan setelah berakhirnya proses pembelajaran. Peneliti berperan sebagai praktisi. Maksudnya yang akan melaksanakan proses belajar mengajar dalam penelitian ini, dan guru

\section{HASIL DAN PEMBAHASAN}

1. Hasil Berdasarkan data yang diperoleh dari hasil penelitian di lapangan dapat diklasifikasikan kemampuan siswa kelas X SMA Eka sakti Padang mengalami peningkatan hasil belajar siwa, hal ini dapat dilihat dari rata-rata yang diperoleh pada siklus I yakni 6,96 dan mengalami peningkatan pada siklus II yakni 8,57.

\section{Analisis Data Siklus I}

a. Penilaian Proses Data di Kelas X SMA EKA SAKTI Padang

Penilaian pada proses data di kelas didasarkan pada penilaian masing-masing kelompok pada saat bermain peran yang mencakup aspek kerjasama, keaktifan dan keberanian siswa dalam memainkan peranan meperoleh nilai rata-rata 7,1 . sebagai obsever maksudnya pengamat berada di luar aktivitas tetapi masih berada dalam setting peneliti.

Wawancara digunakan untuk memperkuat data observasi yang terjadi di kelas baik dari unsur guru, maupun unsur siswa. Wawancara dilakukan kepada guru yang melakukan tindakan intervensi langsung di kelas, terutama yang berkaitan dengan perencanaan pelaksanaan pembelajaran PPKN dengan menggunakan metode bermain peran. Hasil diskusi ini digunakan sebagai bahan untuk perbaikan perencanaan dan pelaksanaan yang akan dilakukan pada siklus berikutnya. Wawancara juga dilakukan kepada siswa untuk memperoleh data berkaitan dengan proses belajar mengajar berlangsung.

Tes digunakan untuk memperkuat data observasi yang terjadi dalam kelas terutama dalam butir penguasaan materi pembelajaran dari unsur siswa. Hal ini dilakukan untuk memperoleh data yang akurat atas kemampuan siswa memahami pembelajaran PPKN dengan menggunakan metode bermain peran. Instrumen utama penelitian adalah peneliti sendiri, yang juga berperan sebagai perencana, peneliti sebagai praktisi dan juga sebagai pelaksana. Peneliti sebagai instrumen utama bertugas menyaring, menilai, menyimpulkan dan memutuskan data yang digunakan.

\section{b. Penilaian Hasil Tes Akhir}

Nilai yang di dapat siswa berdasarkan pada pelaksanaan tes akhir yang dibagikan oleh guru berupa lembaran soal. Pada akhir pembelajaran, guru membimbing siswa menyimpulkan pelajaran. Hal ini dilakukan dengan cara menanyakan tentang pendapatnya mengenai tentang pembelajaran yang telah dilakukan, nilai rata-rata pada hasil tes Akhir adalah 6,69

\section{c. Data Ketuntasan Belajar Siswa Kelas X SMA Eka sakti Padang}

Ketuntasan belajar siswa pada pelaksanaan pembelajaran yang terdapat di siklus I adalah $69,6 \%$ dengan $38,46 \%$ mengalami ketuntasan dan $61,53 \%$ belum tuntas. Dari keseluruhan pelaksanaan pembelajaran pada 
langkah-langkah siklus I, Nilai rata-rata yang didapatkan siswa secara keseluruhan adalah 6,48.

Dari hasil diskusi dengan guru kelas, maka diperoleh hal-hal sebagai berikut:

a) Waktu bermain peran terlalu sedikit.

b) Anak masih susah melafalkan dialog koperasi sekolah.

c) Hasil dialog koperasi sekolah yang diperoleh siswa sedikit memuaskan berada pada taraf sedang.

\section{Analisis Data Siklus II}

\section{a. Penilaian Proses Data di Kelas X SMA EKA SAKTI Padang}

Penilaian pada proses data di kelas didasarkan pada penilaian masing-masing kelompok pada saat bermain peran yang mencakup aspek kerjasama, keaktifan dan keberanian siswa dalam memainkan peranan meperoleh nilai rata-rata 7,5.

\section{b. Penilaian Hasil Tes Akhir}

Nilai yang di dapat siswa berdasarkan pada pelaksanaan tes akhir yang dibagikan oleh guru berupa lembaran soal. Pada akhir pembelajaran, guru membimbing siswa menyimpulkan pelajaran. Hal ini dilakukan dengan cara menanyakan tentang pendapatnya mengenai tentang pembelajaran yang telah dilakukan, nilai rata-rata pada hasil tes Akhir adalah 8,57

c. Data Ketuntasan Belajar Siswa Kelas X SMA Eka sakti Padang

Ketuntasan belajar siswa pada pelaksanaan pembelajaran yang terdapat di siklus II adalah 85,7\% dengan 88,46\% mengalami ketuntasan dan $11,53 \%$ belum tuntas. Dari keseluruhan pelaksanaan pembelajaran pada langkah-langkah siklus II, Nilai rata-rata yang didapatkan siswa secara keseluruhan adalah 8,57. Hal itu dapat dilihat dari beberapa hal yang ada dibawah ini:

1. Keberhasilan guru

a) Guru sudah lebih leluasa menyampaikan dan menggunakan langkah-langkah dalam pembelajaran.

b) Penggunaan waktu dalam pembelajaran pun sudah maksimal. c) Setiap kelompok dapat dibimbing dengan baik.

2. Keberhasilan siswa.

a) Keaktifan siswa sudah terlihat dengan baik.

b) Siswa yang ditunjuk bersedia dengan senang hati untuk tampil ke depan kelas melaporkan hasil diskusinya.

c) Nilai yang didapat siswa sudah menampakkan hasil yang memuaskan, baik nilai disaat proses pembelajaran maupun diskusi kelompok dan nilai tes akhir serta ketuntasan belajar siswa.

2. Pembahasan

Peningkatan hasil belajar siswa dengan menggunakan metode bermain peran dalam pembelajaran PPKN di kelas X SMA Eka sakti Padang. Dari fokus bahasan tersebut kemudian dibahas implikasi hasil penelitian bagi pengembangan pembelajaran PPKN.

a) Pembahasan Siklus I

Dari analisis penelitian siklus I nilai ratarata kelas baru mencapai 6,96. Berdasarkan hasil pengamatan siklus I yang diperoleh maka direncanakan untuk melakukan siklus II. Guru harus dapat memperhatikan perbedaan yang ada pada siswa karena tiap individu mempunyai karakteristik yang berbeda. Menurut Rochman Natawijaya (dalam Rosna, 2006:43) “ Belajar adalah proses pembinaan yang terus menerus terjadi dalam diri individu yang tidak ditentukan oleh unsur keturunan, tetapi lebih banyak ditentukan oleh faktor-faktor dari luar anak." Dalam belajar siswa banyak memperoleh dari guru, maka guru harus lebih memahami kembali ketiga aspek dalam pendidikan yaitu yang belajar, proses belajar dan situasi belajar. Yang belajar adalah anak didik atau siswa yang secara individu atau kelompok mengikuti proses pembelajaran dalam suasana tertentu.

b) Pembahasan Siklus II

Dari hasil analisis penelitian siklus II sudah mencapai $85,7 \%$ dan nilai rata-rata kelas 8,57 Berdasarkan hasil pengamatan siklus II yang diperoleh, maka pelaksanaan siklus II sudah baik dan guru sudah berhasil dalam usaha peningkatan hasil belajar siswa dalam pembelajaran pemilihan ketua kelas dengan menggunakan metode bermain peran bagi siswa kelas X SMA Eka sakti Padang. 
Pembelajaran yang disajikan guru pada siklus II sangat baik. Pada proses pembelajaran guru banyak memberikan kesempatan kepada siswa untuk berdiskusi bersama dan bertanya tentang permasalahan yang tidak dimengerti siswa. Untuk itu guru harus mampu menciptakan situasi yang meyenangkan untuk belajar.

\section{KESIMPULAN}

Berdasarkan depenelitian data, analisis data, dan pembahasan mengenai peningkatan aktivitas dan hasil pembelajaran ekonomi dengan strategi role playing di kelas X SMA Eka sakti Padang, dapat disimpulkan bahwa meningkatnya hasil belajar siswa tersebut dapat dilihat dari rata- rata yang diperoleh pada siklus I yakni 6,96 dan mengalami peningkatan pada siklus II yakni 8,57. Hal ini merupakan bukti keberhasilan pelaksanaan penelitian yang telah dilakukan di SMA Eka sakti Padang. 


\section{DAFTAR PUSTAKA}

Darsono. 2004. Strategi Belajar Mengajar. Bandung: Pustaka Setia.

Djafar, T. Zahara. 2001. Kontribusi Strategi Pembelajaran terhadap Hasil Belajar. Padang: FIK UNP.

Harun, R dan Mansur. 2007. Penilaian hasil belajar. Bandung : CV Wacana Prima.

Harris. 2007.

Dalam http://ardhana12.wordpress.com. (diakses 27 Juni 2013).

Nana, Sudjana. 1996. Cara Belajar Siswa Aktif dalam Proses Belajar Mengajar. Bandung: Sinar Baru Algensindo.

Oemar, Hamalik. 2005. Perencanaan Pengajaran Berdasarkan Pendekatan Sistem. Jakarta : Bumi Aksara.
Oemar, Hamalik. 2008. Proses Belajar Mengajar. Jakarta : Bumi Aksara.

Ritawati, Mahyuddin, dkk. 2008. Hand Out Mata Kuliah Metodologi Penelitian Tindakan Kelas. Padang : UNP.

Slameto. 1995. Belajar dan Faktor-faktor yang Mempengaruhinya. Jakarta: Rineka Cipta.

Syaiful Bahri Djamarah, dkk. 2006. Strategi Belajar Mengajar. Jakarta : Rineka Cipta

Udin S. Winataputra, dkk. 2006. Materi Pembelajaran PPKN SMP. Jakarta: Universitas Terbuka.

Zahara, Djafar. 2001. Konstribusi Strategi Pembelajaran Terhadap Hasil Belajar. Padang : FIP UNP. 